\title{
Oxidative stress in relation to two different pathologies in metabolic syndrome patients
}

\begin{tabular}{ccc}
\hline Sanaa Gadbaan Hama* & Ava Tahir Ismaeel* & Showan Dawood Hussain* \\
\hline Abstract
\end{tabular}

Background and objective: Little is known about the status of redox balance and hypertensive nondiabetic and diabetic nonhypertensive metabolic syndrome patients and its relation to metabolic syndrome components in both pathological conditions. This study aimed to assess the association of redox balance with components of metabolic syndrome in "diabetic and hypertensive, metabolic syndrome" patients to find out which pathology can give a powerful evidence for a possible association with oxidative stress.

Methods: The total oxidative capacity, total antioxidant capacity, lipid profile and fasting serum glucose were measured in serum of 35 healthy subjects, 33 hypertensive nondiabetic and 21 diabetic nonhypertensive, metabolic syndrome patients. The body mass index and waist circumference were also measured. All groups were age and gender matched.

Results: In stratified groups, the highly significant total oxidative capacity, total antioxidant capacity and oxidative stress index were shown in diabetic and hypertensive groups respectively compared with healthy control group, with no significant effect for diabetes on total oxidative capacity and oxidative stress index compared to hypertension condition.

Conclusion: Although the presence of significant higher total oxidative capacity in both study pathologies compared to healthy control, however among metabolic syndrome patients neither hypertension nor diabetes mellitus achieved more dominant to total oxidative capacity.

Keywords: Metabolic syndrome; Total oxidative capacity; Total antioxidant capacity.

\section{Introduction}

One of the most common non communicable diseases worldwide is diabetes mellitus (DM) with over $80 \%$ of living in low- and middle-income countries. ${ }^{1}$ It is suggested that in 2030 , one person will be diabetic for every ten adults, with the largest prevalence occurring in developing countries. $^{2}$ In diabetes mellitus several enzymatic and non-enzymatic pathways mainly in mitochondria, include oxidative stress reactions, the auto-oxidation of glucose in diabetes for increase energy generation usually associated with oxidative stress imbalance. In cells, usually a balance present between antioxidants elimination and free radical formation. The gradual increase in free radicals and decline in antioxidant defense mechanism potential is the fact linking diabetes mellitus with oxidative stress. $^{3}$ In hyperglycemic condition, the non-enzymatic process of oxidative stress causes direct elevation in reactive oxygen species formation. In this path, glucose reacts with proteins which cause progression in advanced glycation end products and changes protein and cellular/immune function. This is from one hand, binding of advanced glycation products with their receptor is enhanced cell signaling pathways and reactive oxygen species formation during the biological process at multiple steps this is from another hand. ${ }^{4}$ Insulin resistance (IR) mediated by oxidative stress (OS), and its progression to glucose intolerance and starting of DM is associated with an increase in the oxidative stress

* Department of Clinical Analysis, College of Pharmacy, Hawler Medical University, Erbil, Iraq. 
process. This, subsequently, promote the appearance of atherosclerotic complications, ${ }^{5}$ and may participate in increase of several micro- and macrovascular lesion as the long term complications associated with diabetes. ${ }^{6,7}$ Oxidative stress considered as a key player in the pathogenesis of hypertension nowadays. A reduction in glutathione peroxidase and superoxide dismutase activity has been showed in newly diagnosed and untreated hypertensive patients, which are inversely correlated with blood pressure. The release of hydrogen peroxide is also higher in hypertensive subjects. Furthermore, hypertensive patients have higher lipid hydroperoxide production. $^{8}$ The elevated level of serum cholesterol, triglyceride (TG), very low density lipoprotein cholesterol (VLDL) has been shown in patients with hypertension. It has been shown that oxidized lipoprotein inactivates nitric oxide (NO) and aggravates hypertension. It is well known that superoxide also rapidly inactivates endothelium-derived nitric oxide, the most important endogenous vasodilator, thereby promoting vasoconstriction. ${ }^{9}$ Oxidative stress is also markedly raised in hypertensive patients with renovascular disease. ${ }^{8}$ The metabolic syndrome (MetS) is considered as a major cause of type 2 diabetes and cardiovascular diseases, recently it has become one of the major public health challenges worldwide. There is a growing belief, however, that obesity, especially visceral obesity, may play an important role in the development of the syndrome. Visceral adiposity seems to be an independent predictor of insulin sensitivity, impaired glucose tolerance, dyslipidemia and elevated blood pressure. ${ }^{10}$ An increasing number of studies confirm that oxidative stress, chronic inflammation and angiogenesis all play important roles in the pathogenesis of MetS as mentioned in above texts. However, little is known about the status of redox balance and hypertensive nondiabetic and diabetic nonhypertensive metabolic syndrome patients and its relation to MetS components in both pathological conditions. Thus, we intended to assess the association of redox balance with components of metabolic syndrome in "diabetic MetS, hypertension MetS" patients to find out which pathology can give powerful evidence for a possible association with oxidative stress.

\section{Methods}

This case-control study was carried out in the Department of Clinical Analysis, College of pharmacy, Hawler Medical University, Erbil, from October 2015 to April 2016. The data were collected directly from patients in Rizgary Teaching Hospital about their lifestyle habits, smoking, drinking, medications history, anthropometric information (waist circumference, height, and weight) and arterial pressure measurement were obtained before blood collection. The exclusion criteria included past history of stroke, coronary artery disease, peripheral vascular disease, smoking and drinking, vitamin supplement, drug lowering body weight or lowering lipid, exercise and pregnant or breastfeeding women. The prevalence of metabolic syndrome (MetS) was assessed according to the criteria of WHO. ${ }^{11}$ Diagnosis of metabolic syndrome was established, when three or more of the following was presented: fasting serum, glucose level equal or greater than 110 $\mathrm{mg} / \mathrm{dl}$, triglycerides level more than 150 $\mathrm{mg} / \mathrm{dl}, \mathrm{HDL}$-cholesterol less than $40 \mathrm{mg} / \mathrm{dl}$ for males and less than $50 \mathrm{mg} / \mathrm{dl}$ for females, blood pressure equal or more than $130 / 85 \mathrm{~mm} \mathrm{Hg}$, males waist circumference more than $102 \mathrm{~cm}$ and for female more than $88 \mathrm{~cm}$. This study included three groups of age and gender matched subjects. After overnight fasting for 12 hours, the blood sample was collected from the patient for estimation of serum, lipid profile, glucose, total antioxidant capacity (TAC) and total oxidative capacity (TOC). 
The biomarkers (serum, glucose, total cholesterol, triglyceride, HDL-cholesterol, LDL-cholesterol) were estimated by standard procedures. Colorimetric test by ELISA (commercial kit from Labor Diagnostika Nord (LDN) ) for quantitative determination of total oxidative capacity (TOC) and total antioxidant capacity (TAC). Statistical analysis:

Statistical analyses were done using SPSS version 21 computer software (Statistical Package for Social Sciences) Microsoft Excel 2010. All the tested measurements were shown to be normally distributed quantitative continuous outcome variables (Semirnove- Kolmogorov test was used). Such variables distribution are described by mean, SE (standard error). The difference in mean between more than two groups ANOVA test is the preferable to express about the statistical significance. A $P$ value equal or less than 0.05 was considered statistically significant. When ANOVA model shows a statistically significant difference in oxidative stress markers (TOC, TAC, OSI) further exploration of the statistical significance of the difference in mean between every two groups was assessed by LSD (least significant difference) test. The Pearson's linear correlation coefficient was used to investigate the statistical significance, direction and strength of linear correlation between two quantitative normally distributed variables. To measure the effect size for the difference between two means, we used Cohen's $d$, which can be compared across different variables and studies, no unit of measurement. Cohen's $d=$ (mean1-mean2) $/$ Pooled SD of the 2 groups. Cohen's $d<0.3$ (small effect), 0.3-0.7 (medium effect), while 0.8 and higher is a (large effect). ${ }^{1}$

\section{Results}

This study included three groups, the first group was 35 healthy control subjects, the second group was 33 patients with hypertension (nondiabetic) and the third group was 21 patients with diabetes mellitus (nonhypertensive), all groups were age and gender matched. As shown in Table 1 , a statistical significant difference was observed in mean waist circumference and body mass index (BMI) between study groups with $P$ value $\leq 0.05$.

Table1: The difference in (mean \pm SE) between study groups for waist circumference and body mass index.

\begin{tabular}{lcccc}
\hline Healthy controls $)$ & $\begin{array}{c}\text { Hypertensive } \\
\text { nondiabetic } \\
\text { MetS }\end{array}$ & $\begin{array}{c}\text { Diabetic } \\
\text { (not hypertensive) } \\
\text { MetS }\end{array}$ & $\begin{array}{c}\boldsymbol{P} \text { value } \\
\text { (ANOVA) }\end{array}$ \\
\hline Number & $\mathbf{N}(\mathbf{3 5})$ & $\mathbf{N}(\mathbf{3 1})$ & 0.002 \\
$\begin{array}{l}\text { Waist circumference } \\
(\mathbf{c m})\end{array}$ & $(90$ to 119$)$ & $(95$ to 127$)$ & $(90$ to 118$)$ & \\
$\begin{array}{l}\text { Range } \\
\text { Mean } \pm \text { SE }\end{array}$ & $104.8 \pm 1.34$ & $111.7 \pm 1.26$ & $106.9 \pm 1.72$ & \\
BMI (Kg/m2) & & & & \\
Range & & & & \\
Mean \pm SE & $(23.3$ to 39.6$)$ & $(27.7$ to 39.7$)$ & $(22.7$ to 52.9$)$ & \\
\hline
\end{tabular}


Table 2 shows no statistically significant study groups but fasting glucose showed difference in mean of lipid profile between a significant difference with $P<0.001$.

Table 2: Serum fasting glucose and lipid profile difference between study groups (mean \pm SE).

\begin{tabular}{|c|c|c|c|c|}
\hline & $\begin{array}{l}\text { Healthy } \\
\text { controls }\end{array}$ & $\begin{array}{c}\text { Hypertensive } \\
\text { (nondiabetic) } \\
\text { MetS }\end{array}$ & $\begin{array}{c}\text { Diabetic } \\
\text { (nonhypertensive) } \\
\text { MetS }\end{array}$ & $\begin{array}{c}P \text { value } \\
\text { (ANOVA) }\end{array}$ \\
\hline Number & $N(35)$ & $N(33)$ & $N(21)$ & \\
\hline \multicolumn{5}{|c|}{$\begin{array}{l}\text { Fasting plasma } \\
\text { glucose (mg/dl) }\end{array}$} \\
\hline Range & (76 to 128$)$ & (82 to 123 ) & (125 to 378$)$ & \multirow[b]{2}{*}{$<0.001$} \\
\hline Mean \pm SE & $103.5 \pm 2.28$ & $102.6 \pm 2.22$ & $238.5 \pm 18.65$ & \\
\hline \multicolumn{5}{|c|}{$\begin{array}{l}\text { Serum total } \\
\text { cholesterol (mg/dl) }\end{array}$} \\
\hline Range & (122 to 306$)$ & (119 to 273 ) & (108 to 279 ) & \multirow[b]{2}{*}{0.68} \\
\hline Mean \pm SE & $175.8 \pm 7.51$ & $184 \pm 7.77$ & $185.3 \pm 10.93$ & \\
\hline \multicolumn{5}{|c|}{ Serum TG (mg/dl) } \\
\hline Range & (31 to 360 ) & (15 to 473 ) & (65 to 500 ) & \multirow[b]{2}{*}{0.11} \\
\hline Mean \pm SE & $140.4 \pm 13.87$ & $189.8 \pm 21.2$ & $182.3 \pm 21.19$ & \\
\hline \multicolumn{5}{|c|}{ Serum LDL (mg/dl) } \\
\hline Range & (10 to 240$)$ & (15 to 190$)$ & (10 to 180$)$ & \multirow[b]{2}{*}{0.99} \\
\hline Mean \pm SE & $96.1 \pm 8.52$ & $94.6 \pm 7.61$ & $95.7 \pm 10.18$ & \\
\hline \multicolumn{5}{|c|}{ Serum HDL (mg/dl) } \\
\hline Range & (14 to 95$)$ & (21 to 90$)$ & (29 to 75 ) & \multirow[b]{2}{*}{0.85} \\
\hline Mean \pm SE & $51.7 \pm 4.22$ & $51.5 \pm 3.23$ & $48.7 \pm 3.41$ & \\
\hline
\end{tabular}


Total antioxidative capacity (TAC) showed no statistically significant difference in mean between study groups with $P>0.05$ as shown in Table 3 . While total oxidative stress showed a highly statistically significant difference between study groups with $P<0.001$, with strong effect for hypertension on oxidative stress capacity compared to healthy control, the difference in mean $(0.105 \mathrm{mmol} / \mathrm{L})$ and Cohen sd value (1.17) and probability of less significant difference $P($ LSD $)<0.001$.
DM also showed a similar effect on oxidative stress capacity compared to the healthy control with the difference in mean $(0.116 \mathrm{mmol} / \mathrm{L})$ and Cohen sd value (1.05) with a probability of less significant difference $P$ (LSD) $<0.001$. The effect of diabetes mellitus on oxidative stress status as compared to hypertensive group showed weak and nonsignificant effect with Cohen sd value 0.1 and $P($ LSD $)=1(\mathrm{NS})$, as shown in Table 3.

Table 3: The difference in mean $\pm S E$ of total oxidative stress and antioxidant capacity between the study groups, with Cohen's $d$ effects.

\begin{tabular}{|c|c|c|c|c|}
\hline & $\begin{array}{l}\text { Healthy } \\
\text { controls }\end{array}$ & $\begin{array}{c}\text { Hypertensive } \\
\text { (nondiabetic) } \\
\text { MetS }\end{array}$ & $\begin{array}{c}\text { Diabetic } \\
\text { (nonhypertensive) } \\
\text { MetS }\end{array}$ & $\begin{array}{l}P \text { value } \\
\text { (ANOVA) }\end{array}$ \\
\hline Number & $\mathrm{N}(35)$ & $N(33)$ & $N(21)$ & \\
\hline \multicolumn{5}{|c|}{$\begin{array}{l}\text { TAC (total anti-oxidant } \\
\text { capacity) }\end{array}$} \\
\hline Range & (2.3 to 4.4$)$ & (0.5 to 4.5$)$ & (2.3 to 4$)$ & \multirow{2}{*}{0.55} \\
\hline Mean \pm SE & $3.15 \pm 0.098$ & $2.94 \pm 0.19$ & $3.06 \pm 0.102$ & \\
\hline \multicolumn{5}{|l|}{$\begin{array}{l}\text { TOS (total oxidative } \\
\text { stress) }\end{array}$} \\
\hline Range & (0.002 to 0.333$)$ & (0.087 to 0.555$)$ & (0.067 to 0.614$)$ & \multirow{2}{*}{$<0.001$} \\
\hline Mean \pm SE & $0.153 \pm 0.0157$ & $0.258 \pm 0.0167$ & $0.269 \pm 0.0296$ & \\
\hline \multicolumn{5}{|c|}{$\begin{array}{l}\text { Effect of hypertensive } \\
\text { compared to healthy } \\
\text { controls }\end{array}$} \\
\hline Difference in mean & 0.105 & & & \\
\hline Cohen's d & 1.17 & & & \\
\hline$P(L S D)$ & $<0.001$ & & & \\
\hline \multicolumn{5}{|c|}{$\begin{array}{l}\text { Effect of DM compared } \\
\text { to healthy controls }\end{array}$} \\
\hline Difference in mean & 0.116 & & & \\
\hline Cohen's d & 1.05 & & & \\
\hline $\mathrm{P}(\mathrm{LSD})$ & $<0.001$ & & & \\
\hline \multicolumn{5}{|c|}{$\begin{array}{l}\text { Effect of DM compared } \\
\text { to hypertensive }\end{array}$} \\
\hline Difference in mean & 0.011 & & & \\
\hline Cohen's d & 0.10 & & & \\
\hline$P(L S D)$ & 1 & & & \\
\hline [NS]: non significant & & & & \\
\hline
\end{tabular}


Oxidative stress index (OSI) showed a highly statistically significant difference between study groups with $P<0.001$, and hypertensive, diabetes had a strong effect and statistically significant on OSI compare to healthy control with Cohen sd values $0.98,1.03$ respectively. A weak, statistically nonsignificant effect of diabetes on OSI was found compared to the hypertensive group with Cohen $s d=0.26$, $P($ LSD $)>0.05$, as shown in Table 4 .

Table 4: The difference in mean \pm SE of oxidative stress index between study groups, with Cohen's $d$ effects.

\begin{tabular}{cccc}
$\begin{array}{c}\text { Healthy } \\
\text { controls } \\
\mathrm{N}(35)\end{array}$ & $\begin{array}{c}\text { Hypertensive } \\
\text { with Metabolic } \\
\text { Syndrome } \\
\mathrm{N}(33)\end{array}$ & $\begin{array}{c}\text { DM } \\
\text { (not hypertensive) }\end{array}$ & $\begin{array}{c}P \text { value } \\
\text { (ANOVA) }\end{array}$ \\
\hline
\end{tabular}

OSI (oxidative stress index)

$\begin{array}{lllll}\text { Range } & (0 \text { to } 0.132) & (0.022 \text { to } 0.354) & (0.022 \text { to } 0.24) & \\ \text { Mean } \pm \text { SE } & 0.052 \pm 0.006 & 0.111 \pm 0.0136 & 0.093 \pm 0.0122 & <0.001\end{array}$

\section{Effect of hypertensive compared to healthy controls}

Difference in mean

Cohen's d

$P($ LSD $)$

$<0.001$

\section{Effect of DM compared to healthy controls}

Difference in mean

Cohen's d

$P($ LSD $)$

\section{Effect of DM compared to hypertensive}

Difference in mean

$-0.018$

Cohen's d

$-0.26$

$P($ LSD $)$

0.8 
To explores possible association between serum OSI and study parameters among patients of both pathological groups, serum OSI was transformed into an ordered categorical variable based on quartile (dividing the sample into four quarters based on serum variable after ordering it from minimum to maximum value). The resulting categorical variable will have three categories: The first one is the lowest quartile and the last one is the highest quartile. The remaining two central quartiles are merged into the "inter-quartile range) or what we call the central $50 \%$ of data. Among hypertensive group, the obvious positive association between OSI quartiles and waist circumference was found, but statistically nonsignificant difference with $P=0.07$, but a highly statistically significant positive association has been found between OSI quartile and serum triglyceride with $P=0.002$ (Table 5).

Table 5: The association of oxidative stress index ( OSI) with study parameters among hypertensive nondiabetic group only.

\begin{tabular}{|c|c|c|c|c|}
\hline & \multicolumn{3}{|c|}{ OSI (oxidative stress index)-quartiles } & \multirow[b]{2}{*}{$\begin{array}{l}P \text { value } \\
\text { (ANOVA) }\end{array}$} \\
\hline & $\begin{array}{c}\text { First (lowest) } \\
\text { quartile } \\
(<=.064)\end{array}$ & $\begin{array}{c}\text { Average } \\
\text { (interquartile range) } \\
0.065-0.123\end{array}$ & $\begin{array}{l}\text { Fourth (highest } \\
\text { quartile } \\
(0.124+)\end{array}$ & \\
\hline $\mathrm{N}$ & 8 & 16 & 9 & \\
\hline \multicolumn{5}{|c|}{$\begin{array}{l}\text { Waist circumference } \\
\text { (cm) }\end{array}$} \\
\hline Range & (95 to 114 ) & (102 to 127$)$ & (102 to 119$)$ & \multirow[b]{2}{*}{0.07} \\
\hline Mean \pm SE & $107 \pm 2.64$ & $113.1 \pm 1.79$ & $113.3 \pm 1.95$ & \\
\hline \multicolumn{5}{|c|}{ BMI (Kg/m2) } \\
\hline Range & (30.6 to 36$)$ & (28.7 to 39.7$)$ & (27.7 to 36.4$)$ & \multirow[b]{2}{*}{0.33} \\
\hline Mean \pm SE & $32.6 \pm 0.64$ & $34.3 \pm 0.86$ & $31.3 \pm 0.81$ & \\
\hline \multicolumn{5}{|c|}{$\begin{array}{l}\text { Fasting serum } \\
\text { glucose (mg/dl) }\end{array}$} \\
\hline Range & (85 to 122$)$ & (82 to 123 ) & (82 to 120$)$ & \multirow[b]{2}{*}{0.95} \\
\hline Mean \pm SE & $104.8 \pm 4.14$ & $100.5 \pm 3.38$ & $104.3 \pm 4.36$ & \\
\hline \multicolumn{5}{|c|}{$\begin{array}{l}\text { Serum total } \\
\text { cholesterol (mg/dl) }\end{array}$} \\
\hline Range & (138 to 265$)$ & (119 to 272$)$ & (138 to 273 ) & \multirow[b]{2}{*}{0.76} \\
\hline Mean \pm SE & $184.8 \pm 14.33$ & $179.4 \pm 11.38$ & $191.6 \pm 16.82$ & \\
\hline \multicolumn{5}{|c|}{ Serum TG (mg/dl) } \\
\hline Range & (15 to 211$)$ & (70 to 296$)$ & (97 to 473 ) & \multirow[b]{2}{*}{0.002} \\
\hline Mean \pm SE & $132.3 \pm 25.5$ & $156.6 \pm 18.43$ & $300.1 \pm 53.09$ & \\
\hline \multicolumn{5}{|c|}{ Serum HDL (mg/dl) } \\
\hline Range & (35 to 81$)$ & (21 to 90 ) & (36 to 80 ) & \multirow[b]{2}{*}{0.28} \\
\hline Mean \pm SE & $52.3 \pm 6.25$ & $45.4 \pm 4.86$ & $61.8 \pm 4.74$ & \\
\hline \multicolumn{5}{|c|}{ Serum LDL (mg/dl) } \\
\hline Range & (70 to 165 ) & (15 to 190$)$ & (18 to 111 ) & \multirow{2}{*}{0.1} \\
\hline Mean \pm SE & $105.6 \pm 11.3$ & $102.7 \pm 12.26$ & $70.6 \pm 12.14$ & \\
\hline
\end{tabular}


The diabetic nonhypertensive group showed a positive association between waist circumference and quartiles of OSI but was statistically nonsignificant $(P=0.09)$ as shown in Table 6. Table 7 shows a weak, but statistically significant linear correlation between total oxidative stress and waist circumference $(r=0.367$, $P=0.036$ ). With the absence of statistical significant linear correlation between TOS and serum, lipid profile, fasting blood sugar and body mass index in hypertensive group.

Table 6: The association of OSI with study parameters among DM (not hypertensive) group.

\begin{tabular}{lcccc}
\hline & $\begin{array}{c}\text { First (lowest) } \\
\text { quartile } \\
(<=.064)\end{array}$ & $\begin{array}{c}\text { Average } \\
\text { (interquartile } \\
\text { range) } \mathbf{0 . 0 6 5}- \\
\mathbf{0 . 1 2 3}\end{array}$ & $\begin{array}{c}\text { Fourth (highest } \\
\text { quartile } \\
\text { (0.124+) }\end{array}$ & $\begin{array}{c}\boldsymbol{P} \text { value } \\
\text { (ANOVA } \\
\text { trend) }\end{array}$ \\
\hline $\mathrm{N}$ & 6 & 12 & 3 & \\
$\begin{array}{l}\text { Waist circumference (cm) } \\
\text { Range }\end{array}$ & $(90$ to 116$)$ & $(96$ to 117$)$ & $(106$ to 118$)$ & 0.09 \\
Mean \pm SE & $104.5 \pm 3.63$ & $106.3 \pm 2.05$ & $114 \pm 4$ & \\
BMI (Kg/m2) & $(22.7$ to 35.9$)$ & $(26.7$ to 52.9$)$ & $(28.8$ to 36.9$)$ & 0.73 \\
$\begin{array}{l}\text { Range } \\
\text { Mean } \pm \text { SE }\end{array}$ & $31.4 \pm 2.23$ & $33 \pm 2.03$ & $33 \pm 2.34$ & \\
$\begin{array}{l}\text { Fasting serum glucose } \\
\text { (mg/dl) }\end{array}$ & & & & \\
Range & $(125$ to 282$)$ & $(135$ to 378$)$ & $(183$ to 378$)$ & 0.12 \\
$\begin{array}{l}\text { Mean } \pm \text { SE } \\
\text { Serum total cholesterol } \\
\text { (mg/dl) }\end{array}$ & $192.7 \pm 22.43$ & $249 \pm 26.16$ & $288 \pm 56.79$ & \\
Range & & & & \\
$\begin{array}{l}\text { Mean } \pm \text { SE } \\
\text { Serum TG (mg/dl) }\end{array}$ & $(116$ to 279$)$ & $(108$ to 223$)$ & $(169$ to 275$)$ & 0.26 \\
$\begin{array}{l}\text { Range } \\
\text { Mean } \pm \text { SE }\end{array}$ & $185 \pm 26.72$ & $175.4 \pm 11.34$ & $225.7 \pm 30.82$ & \\
\hline
\end{tabular}

Table 7: Linear correlation coefficient among Hypertensive (nondiabetic) group.

\begin{tabular}{lcc}
\hline & & TOS (total oxidative stress) $\mathrm{mmol} / \mathbf{L}$ \\
\hline TOS (total oxidative stress) mmol/L & $\mathrm{r}=1$ & $\mathrm{P}<0.001$ \\
TAC (total anti-oxidant capacity) $\mathrm{mmol} / \mathrm{L}$ & $\mathrm{r}=-0.012$ & $\mathrm{P}=0.95$ \\
OSI (oxidative stress index) & $\mathrm{r}=0.326$ & $\mathrm{P}=0.06$ \\
Age (years) & $\mathrm{r}=0.077$ & $\mathrm{P}=0.67$ \\
Waist circumference $(\mathrm{cm})$ & $\mathrm{r}=0.367$ & $\mathrm{P}=0.036$ \\
BMI $\left(\mathrm{Kg} / \mathrm{m}^{2}\right.$ ) & $\mathrm{r}=0.084$ & $\mathrm{P}=0.64$ \\
Fasting serum glucose $(\mathrm{mg} / \mathrm{dl})$ & $\mathrm{r}=0.164$ & $\mathrm{P}=0.36$ \\
Serum total colesterol $(\mathrm{mg} / \mathrm{dl})$ & $\mathrm{r}=0.036$ & $\mathrm{P}=0.84$ \\
Serum TG $(\mathrm{mg} / \mathrm{dl})$ & $\mathrm{r}=0.312$ & $\mathrm{P}=0.08$ \\
Serum HDL $(\mathrm{mg} / \mathrm{dl})$ & $\mathrm{r}=0.259$ & $\mathrm{P}=0.15$ \\
Serum LDL $(\mathrm{mg} / \mathrm{dl})$ & $\mathrm{r}=-0.256$ & $\mathrm{P}=0.15$ \\
\hline
\end{tabular}


In diabetic group, the linear correlation is strong and highly significant between TOS and oxidative stress index $(r=0.976$, $P<0.001$ ), and moderate significant linear correlation between TOS and waist circumference was detected $(r=0.445$, $P=0.04$ ), Table 8.

\section{Discussion}

Metabolic syndrome is multi-factorial pathogenesis, still no single factor has been identified as main factor of syndrome.

Many studies have been reported that the components of MetS, obesity, glucose intolerance, hypertension, often cause oxidative stress and are related with accelerated atherogenesis, ${ }^{10,13-16}$ however, these studies did not investigate the effect of diabetes or hypertension separately on oxidative stress, as components of metabolic syndrome. In this study, we analyzed TAC, TOC, OSI, as overall markers of oxidative stress in hypertensive nondiabetic and diabetic nonhypertensive patients compared to healthy control. Both diabetes mellitus and hypertension have impact on oxidative stress, we found that both TOC, OSI were altered in both groups of metabolic syndrome patients compared to healthy control, this result is not surprising since the metabolic abnormalities (hypertension, diabetes mellitus) which are recognized as being related with altered oxidative stress on the other hand, high BMI and WC in both diabetic and hypertensive study groups indicates that fat accumulation aggravate this difference compare to control group, these data are in good agreement with studies suggesting that systemic oxidative stress correlates with BMI. ${ }^{10,17}$ Previous studies assessed WC as a risk factor for DM2 and cardiovascular diseases, along with the $\mathrm{BMI}^{18}$ and obesity was related to OS, ${ }^{19,20}$ this study showed that both WC and BMI aggravate OS. Hypertension, but not diabetes, showed statistically nonsignificant effect on TOC. The nonsignificant difference in oxidative status between the two study pathologies with adjustment of other study variables (no difference in the distribution of gender and age) indicated that the oxidative status in both diseases is similar. The same is suggested for total antioxidant capacity in this study, as shown to be approximately similar (2.94 0.19 vs. $3.06 \pm 0.102)$ for hypertension and diabetes respectively, this means the defense mechanism in these diseases are similar. A growing belief suggests that obesity, especially visceral obesity, may play an important role in the development of metabolic syndrome. This belief was confirmed by our results as

Table 8: Linear correlation coefficient among DM (not hypertensive) group.

\begin{tabular}{lcc}
\hline & & TOS (total oxidative stress) $\mathrm{mmol} / \mathrm{L}$ \\
\hline TOS (total oxidative stress) mmol/L & $\mathrm{r}=1$ & $\mathrm{P}<0.001$ \\
TAC (total anti-oxidant capacity) $\mathrm{mmol} / \mathrm{L}$ & $\mathrm{r}=-0.517$ & $\mathrm{P}=0.016$ \\
OSI (oxidative stress index) & $\mathrm{r}=0.976$ & $\mathrm{P}<0.001$ \\
Age (years) & $\mathrm{r}=0.199$ & $\mathrm{P}=0.39$ \\
Waist circumference $(\mathrm{cm})$ & $\mathrm{r}=0.445$ & $\mathrm{P}=0.043$ \\
BMI $\left(\mathrm{Kg} / \mathrm{m}^{2}\right.$ ) & $\mathrm{r}=0.179$ & $\mathrm{P}=0.44$ \\
Fasting serum glucose $(\mathrm{mg} / \mathrm{dl})$ & $\mathrm{r}=0.385$ & $\mathrm{P}=0.08$ \\
Serum total cholesterol $(\mathrm{mg} / \mathrm{dl})$ & $\mathrm{r}=0.228$ & $\mathrm{P}=0.32$ \\
Serum TG $(\mathrm{mg} / \mathrm{dl})$ & $\mathrm{r}=0.013$ & $\mathrm{P}=0.96$ \\
Serum HDL $(\mathrm{mg} / \mathrm{dl})$ & $\mathrm{r}=-0.378$ & $\mathrm{P}=0.09$ \\
Serum LDL $(\mathrm{mg} / \mathrm{dl})$ & $\mathrm{r}=0.355$ & $\mathrm{P}=0.11$ \\
\hline
\end{tabular}


a moderate positive correlation between TOC and WC was shown in both study pathological MetS groups. This supports the idea that adipose tissue, mainly visceral which reflected by waist circumference, is considered the most obvious sign and risk factor for chronic metabolic abnormalities and oxidative stress may be an independent predictor of insulin sensitivity, impaired glucose tolerance, dyslipidemia and elevated blood pressure $^{-1,17,21}$ Some of these chronic metabolic abnormalities were revealed in this study.

\section{Conclusion}

Both study pathologies showed a higher total oxidative capacity as compared to healthy control, but neither hypertension nor diabetes mellitus achieved dominant to total oxidative capacity among metabolic syndrome patients. Waist circumference was the most powerful component of metabolic syndrome which affects the total oxidative capacity in both study pathologies (hypertension, diabetes mellitus) and this supported by a significant positive association between serum triglyceride and oxidative stress index quartile. Among metabolic syndrome components (lipids, BMI, blood sugar and others), waist circumference seems to be the only component links oxidative stress to metabolic syndrome.

\section{Conflicts of interest}

The authors report no conflicts of interest.

\section{References}

1.Bandeira SM, Pires AS, Guedes GS, Gelain DP, Mary S L, Fonseca LJ, et al.' Characterization of Blood Oxidative Stress in Type 2 Diabetes Mellitus Patients: Increase in Lipid Peroxidation and SOD Activity'. Oxidative Medicine and Cellular Longevity 2012; 2012:819310.

2. Wild SH, Roglic G, Green A, Sicree R, King H. Global prevalence of diabetes: estimates for the year 2000 and projections for 2030. Diabetes Care 2004; 27:1047-53.

3. Dandu AM, Inamdar NM. Evaluation of beneficial effect of antioxidant properties of some plants in diabetic rats. Pak J pharma Sci2009; 22(1): 49-52.
4. Khan AN, Khan RA, Ahmad M, Mushtaq N. Role of antioxidant in oxidative stress and diabetes Mellitus. Journal of Pharmacognosy and Phytochemistry 2015; 3(6):217- 20.

5. Ceriello A, Motz E. Is oxidative stress the pathogenic mechanism underlying insulin resistance, diabetes, and cardiovascular disease? The common soil hypothesis revisited. Arteriosclerosis, Thrombosis, and Vascular Biology 2004; 24(5):816-23.

6. Halliwell B, Gutteridge JMC. Free Radicals in Biology and Medicine. $4^{\text {th }}$ ed. New York, NY, USA:Oxford University Press; 2007.

7. Negre SA, Salvayre R, Auge N, Pamplona R, Porterot M. Hyperglycemia and glycation in diabetic complications. Antioxidants and Redox Signaling 2009; 11(12):3071-109.

8. Baradaran A, Nasri H, Kopae MR. Oxidative stress and hypertension: Possibility of hypertension therapy with antioxidants. J Res Med Sci 2014; 19(4):358-67.

9. Zicha J, Dobesova Z, Kunes J. Relative deficiency of nitric oxide-dependent vasodilation in salthypertensive Dahl rats: the possible role of superoxide anions. J Hypertens 2001; 19: 247-54.

10. Mahjoub S, Masrour Roudsari J. Role of oxidative stress in pathogenesis of metabolic syndrome. Caspian J Intern Med 2014; 3(1): 386-96.

11. Crook MA. Clinical chemistry and metabolic medicine. $7^{\text {th }}$ ed.338 Euston Road, London: Hodder Arnold; 2006. P. 174-97.

12. Sullivan GM , Feinn R. Using Effect Size-or Why the $P$ Value Is Not Enough. J Grad Med Educ 2012; 4(3):279-82.

13. Kim CH, Younossi ZM. Nonalcoholic fatty liver disease: a manifestation of the metabolic syndrome. Cleve Clin J Med 2008; 75:721-8.

14. Eschwege E. The dysmetabolic syndrome, insulin resistance and increased cardiovascular (CV) morbidity and mortality in type 2 diabetes: aetiological factors in the development of $\mathrm{CV}$ complications. Diabetes Metab 2003: 29; 6S19-27.

15. Rosen P, Nawroth PP, King G, Moller W, Tritschler HJ, Packer L. The role of oxidative stress in the onset and progression of diabetes and its complications: a summary of a Congress Series sponsored by UNESCO-MCBN, the American Diabetes Association and the German Diabetes Society. Diabetes Metab Res Rev 2001; 17:189-212.

16. Senti $M$, Tomas $M$, Fito $M$, Weinbrenner $T$, Covas MI, Sala J, et al. Antioxidant paraoxonase 1 activity inthe metabolic syndrome. J Clin Endocrinol Metab 2003; 88:5422-6.

17. Taheri E, Djalali M, Saedisomeolia A, Moghadam AM, Djazayeri $A$. The relationship between the activates of antioxidant enzymes in red blood cells and body mass index in Iranian type 2 diabetes 
and healthy subjects. J Diabetes Metabolic Disorders 2012; 11(3):1-5.

18. Janiszewski PM, Janssen I, Ross R. "Does waist circumference predict diabetes and cardiovascular disease beyond commonly evaluated cardiometabolic risk factors?". Diabetes Care 2007; 30:3105-9.

19. Archivio MD, Annuzzi G, Varı R. Predominant role of obesity/insulin resistance in oxidative stress development,". Europ J Clin Invest 2012; 42(1):70 $-8$.

20. Urakawa $H$, Katsuki A, Sumida $Y$. Oxidative stress is associated with adiposity and insulin resistance in men. J Clin Endocrinol Metab 2003; 88(10):4673-6.

21.Tabur $S$, Nur-Torun $T$, Suzan-Tabur NA, Nur-Torun A, Aksoy N, Sabuncu $T$, et al. Non-diabetic metabolic syndrome and obesity do not affect serum paraoxonase and arylesterase activities but do affect oxidative stress and inflammation. Europ J Endocrinol 2010; 162:53541. 